\title{
Tissue Procurement and Distribution Shared Resource
}

National Cancer Institute

\section{Source}

National Cancer Institute. Tissue Procurement and Distribution Shared Resource. NCI

Thesaurus. Code C39541.

The T issue Procurement and Distribution Shared Resource provides centralized procurement, storage, and transfer of neoplastic and control human tissues from clinical and surgical pathology, autopsy, and cytology; procurement of physiologic fluids, bone marrow and other specimens for research purposes as requested by Cancer Center investigators, tissue preparation according to the protocol and samples preservation in compliance with rules of the HIC and HIPPA, as well as access to tissues through the Cooperative Human T issue Network, handling and storing samples, and maintains information on banked samples. 